\title{
GIT1 wt Allele
}

National Cancer Institute

\section{Source}

National Cancer Institute. GIT1 wt Allele. NCI Thesaurus. Code C52633.

Human GIT 1 wild-type allele is located in the vicinity of $17 p 11.2$ and is approximately 16 $\mathrm{kb}$ in length. This allele, which encodes ARF GT Pase-activating protein GIT1, is involved in the regulation of both cellular morphology and motility. 